\title{
THE VOICE OF THE ULEMA AND DILEMMA OF THE INDONESIAN ULEMA COUNCIL'S FATWA AMONG LOW LITERATE SOCIETY
}

\author{
Fariz Alnizar \\ Nahdlatul Ulama University of Indonesia, Indonesia \\ E-mail: fariz@unusia.ac.id \\ Achmad Munjid \\ Gadjah Mada University, Indonesia \\ E-mail: munjid@ugm.ac.id
}

\begin{abstract}
Some Islamic movements in Indonesia, which make the fatwas issued by the Indonesian Ulema Council (MUI) a reference for their actions, recently found their momentum after the defense movements called 411 and 212. The proponents of these movements are called Gerakan Nasional Pengawal Fatwa Majelis Ulama Indonesia (GNPFMUI), which means The National Movement of the Guardians of the Indonesian Ulema Council's Fatwa. By the employment of a qualitative approach coupled with a historical-causal paradigm, this article examines the main question, which asks if the proponents of these movements substantially understand the fatwas they defend. The results of the research showed that the fatwas held a dilemmatic position. While some movements have insisted on making them a "sacred opinion" that must be protected and guarded, people do not substantially comprehend the fatwas they defend. This problem is caused by the cultural basis of the Indonesian society, which put more preference on orality than literality or, explicitly, written tradition.
\end{abstract}

Keywords: Indonesian Ulema Council (MUI), Fatwa, Literacy, Orality.

\section{Introduction}

In religious traditions, especially in Islam, a fatwa has a position and a very long history. ${ }^{1}$ At the beginning of the emergence of Islam,

\footnotetext{
1 Muhammad Khalid Masud, Brinkley Messick, and David Powers, Islamic Legal Interpretation: Muftis and Their Fatwas, ed. Muhammad Khalid Masud, Brinkley Messick, and David Powers (London: Harvard University Press, 1996). See also 
when the Prophet Muhammad was alive, he becomes the referral source and the main reference in religious or social rites. Muslims were always asking for opinions or fatwas to the Prophet Muhammad regarding events, phenomena, and also the cases that had never known the law at that time. In the next phase, the tradition of giving fatwas was continued by the Companions, Tàbi' al-Tābi īin, until later by the scholars who were considered authoritative. Regarding the last mentioned, in its development, as noted by Assyaukani that there are two models: personal and institutional. ${ }^{2}$

Lots of Arab countries use personal models, namely by appointing one person who is considered the most legitimate person to be a mufti. Mufti is a person who has the duty to provide solutions and problems of publicity. Meanwhile, there are also those who use institutional models as in Indonesia and also in Malaysia (to name two large examples). In Indonesia, fatwas are not produced by individuals but by institutions. The fatwa institution-in the context of state institutions - is known as the Indonesian Ulema Council (MUI). ${ }^{3}$ This MUI was given the mandate to issue a fatwa on the issue of prosperity that occurred in Indonesia. Even, MUI always claimed that it was a representation of Indonesian Muslims. Thus, the fatwas issued as an attitude and reflection of the opinion of Muslims. ${ }^{4}$

Abdullah bin Mahfuz bin Bayyah, Sināat al-Fatwā wa Fiqh Aqalliyāt (Beirut: Dār alMinhāj, 2007); M. B Hooker, Indonesian Islam: Sosial Change through Contemporary Fatawa (Honolulu: University of Hawai Press, 2003).

2 Luthfi Assyaukanie, "Fatwa and Violence in Indonesia," Journal of Religion and Society, Vol. 11 (2009): 1-21.

${ }^{3}$ Fariz Alnizar, "Pretext for Religious Violence in Indonesia: An Anthropolinguistic Analysis of Fatwas on Ahmadiyya," Studia Islamika, Vol. 26, No. 3 (2019). See also Robin Bush, "Religious Politics and Minority Rights during the Yudhoyono Presidency," in Edward Aspinall, Marcus Mietzner, and Dirk Tomsa (eds.), The Yudhoyono Presidency: Indonesia's Decade of Stability and Stagnation (Singapore: ISEAS, 2015). Also La Jamaa, "Fatwas of the Indonesian Council of Ulama and Its Contributions to the Development of Contemporary Islamic Law in Indonesia," Indonesia Journal of Islam and Muslim Societies, Vol. 8, No. 1 (2018), 29-56, https://doi.org/10.18326/ijims.v8i1.29-56.

4 Ahmad Suaedy, "Pengarusutamaan Fatwa-fatwa Moderat dalam Kebijakan Negara: Suatu Tantangan Baru", in Syafiq Hasyim and Fahmi Syahirul Alim (eds.), Moderatisme Fatwa: Diskursus, Teori, dan Praktik (Jakarta: International Center for Islam and Pluralism (ICIP), 2018) see also Stewart Fenwick, "Eat, Pray, Regulate: The Indonesian Ulama Council and the Management of Islamic Affairs," Journal of Law and Religion, Vol. 2, No. 2 (2018), 271-290, https://doi.org/10.1017/jlr.2018. 23. more explanation see Moch Nur Ichwan and Nina Marinani Noor, "Arah Baru 
Nevertheless, in certain levels of society, such as in mass organizations, there are also special institutions that are tasked with providing solutions to the problems of their people. For example, Nahdlatul Ulama that has the Bahtsul Masail Institute and also Muhammadiyah that has the Tarjih Muhammadiyah Council, which have the task of finding answers to the questions posed to them.

In the current Indonesian context, borrowing Fealy and White's thesis on Islamic Expressing: Religious Life and Politics in Indonesia when people flocked closer to religion, also the conditions in which religion was so diverse, which in certain contexts according to Munjid this era leads and raises such demonstrative individuals towards their various ways (self-religiosity), ${ }^{5}$ interesting to discuss how Indonesian society positions fatwas. ${ }^{6}$ What is the current position of the Indonesian

Majelis Ulama Indonesia," in Noorhaidi Hasan (ed.), Ulama dan Negara Bangsa (Yogyakarta: Pusat Pengkajian Islam, Demokrasi, dan Perdamaian (PusPIDeP), 2019).

5 Ahmad Munjid, "High Demand for Symbols Drive 'Islamic' Black Market"," Jakarta Post, December 6, 2018, http://www.thejakartapost.com/academia/2018 /06/12/high-demand- for-symbols-drive-islamic-black-market.html.

${ }^{6}$ In this context, Bunt said "The phenomenon of online activism in the name of Islam in relation to Cyber Islamic Environments was introduced in Virtually Islamic as an area in which tensions might escalate as Internet technology becomes more widely available and accessible. Various 'Islamic' groups, especially in relation to conflicts in Chechnya, Palestine, Kashmir and Afghanistan, have proved this in online campaigns seeking to promote their cause, and at times disrupt the online activities of their ideological and military opponents. The term e-jihad perhaps has some flexibility within our discussion. It could be associated with hacking, cracking and disruptive technological application; more widely, it could also be applied as a form of propaganda (or e-da'wa?) in order to present specific worldviews-perhaps to a selective and sympathetic audience, but also to a wider global audience (Muslim and other). E-jihad could be extended to discussions on how information technology was applied by groups such as al-Qaeda in order to organize logistics for their campaigns, through the application of email and encrypted files, as well as a means for developing their own strategic intelligence. The notion of jihad in classical Islamic contexts is much broader than the violent associations it has acquired. The term accommodates peaceful spiritual 'striving' and effort in the name of Islam, as well as militaristic activities: just as it could be said that not all battles are conducted by military campaigning, so the battles of the individual Muslim (for example, against the pressures and temptations of the mundane world) can be described as jihad. So whilst e-jihad is a convenient label, technically it could be seen as a misnomer, and many of the expressions of Islam contained on the web might represent this so-called sixth 'pillar' of Islam. See Gary R Bunt, Islam in the 
Ulema Council as an institution that has the legality to issue a fatwa? Do fatwa is still regarded as sacred, mythical, doctrinal, and must be obeyed? Or even further, is the voice of the ulema (voice of scholars) still being heard, or should it be ignored and dumped just like that? Or even in certain contexts, does that mean that the ulema-in their context who are institutionalized in an institution-have begun to lose their authority and voice?

This brief article will try to explore the various questions above by using a set of concepts and approaches. Furthermore, this paper focuses on how the fatwa struggle in Muslims' daily lives is related to the culture of literacy of the Indonesian people.

\section{Fatwa, Religious Opinion, and Religious Authority}

Studies of fatwas and religious authority were also carried out by many researchers. The following will be presented some relevant studies with this short article as an epistemic basis. In the article entitled The Voice of the Ulama: Fatwas and Religious Authorities in Indonesia, Kaptein mentioned the concept of religious authority. In more detail, Kaptein explained how and also how the religious authorities work. In a deeper context, this article also describes the media and what dissemination tools are most often used to grasp religious authority. At this stage, Kaptein saw fatwas as the media most often used to spread religious authority.

By gaining the paradigm of the evolutionism paradigm, Kaptein examines the evolution of fatwas and, at the same time, catalyzes them into traditional, modern, and also collective. The study found that there were three fatwa typologies. First, traditionalist fatwa. This is reflected in work entitled Mubimmat al-Nafäis fì Bayan As'ilatil al-Hadith by Ahmad Dahlan. The characteristic of the traditional fatwa is complete without the name mustafti or the person asking. This means that the identity of the questioner is not displayed in the fatwa. This type of fatwa uses Arabic and pegon Arabic. "... the fatwa was accompanied by a Malay rendering written in Arabic script, the socalled Jawi script."

Digital Age: E-Jihad, Online Fatwas and Cyber Islamic Environments: Critical Studies on Islam (London: Pluto Press, 2003).

${ }^{7}$ Nico J.G Kaptein, “The Voice of the 'Ulamâ': Fatwas and Religious Authority in Indonesia," Archives de Sciences Sociales Des Religions, No. 125 (2004), 115-130, 127.

${ }^{8}$ Ibid., 121. 
The second is called a modern fatwa. In this section, a very striking difference with traditional fatwa is on the identity of the mustafti or questioner. In the Pembela Islam (Islamic Defenders) newspaperwhich is one of the media used as a reference for research-mustafti identity is mentioned. But the identity is lost when the fatwas are recorded, and the mustafti identity is omitted. This is due to the views and considerations that state that the question is asked if in the context of question and answer in the Pembela Islam media are personal, but when transferred to the book the collection of fatwas, these questions become global. This means that the statement shifts to the general question of the audience. Beyond that, the striking difference in modern fatwas is about the use of the language. The language used in modern fatwas is Indonesian. This phase is said to have begun around the 1930s when Ahmad Hassan of PERSIS began Islamic questions and answers in 1929-1935.

Thirdly, collective fatwa. At this stage, the pattern of granting fatwas evolved from the personal as happened to traditional and also modern (i.e. fatwa issued by individuals) shifting to the fatwa phase was issued collectively. The three organizations or institutions that issued this type of fatwa include those examined by the Indonesian Ulema Council (MUI), Nahdlatul Ulama (NU), and also Muhammadiyah. All three-issue fatwas collectively institutionally, not individuals. In this context, the classification of fatwa typologies described by Kaptein does not have clear criteria, namely from what point of view: period, fatwa model, or the issuing institutions (personal or collective). This makes us wonder based on what the classification was done. On the other hand, Kaptein concludes that religious authority was not static; it was very dynamic. "...I have shown that the concept of religious authority is definitely not static, but very much subject to changes in the political, social, educational, and religious landscape in Indonesia." When compared to the 19th century, today, religious authority is not a domain monopolized by scholars alone. ${ }^{10}$ The opening of information sources and also the increasing number of

\footnotetext{
${ }^{9}$ Ibid., 128.

${ }^{10}$ Mohamad Abdun Nasir, "The 'Ulamā' Fatāwā and Challenges to Democracy in Contemporary Indonesia," Islam and Christian-Muslim Relations, Vol. 25, No. 4 (2014), 1-17, https://doi.org/10.1080/09596410.2014.926598.
} 
educated people raises a new phenomenon that those-who are not clerics-also have religious authority. ${ }^{11}$

The relation between the role of clerics, religious authority and also symbolic power that exists in Indonesian society has been discussed by Zulkilfi in The Ulama in Indonesia: between Religious Authorithy and Symbolic Power. This study is based on the search for important literature related to themes about kiai, ulama, power, and also religious authority. By using a critical paradigm, that is a study carried out by in-depth search of books and the results of previous research by criticizing and drawing synthesis between these studies. The analytical method used is comparative interpretative, namely by giving an interpretation and comparing one finding with the other findings made by the previous researcher. The type of analysis used is comparative interpretative by giving an interpretation and also comparing one finding with the other findings that have been done by the previous researchers. ${ }^{12}$

There are several studies and research results that are references and discussions in this article. Especially concerning the study of scholars in Indonesia. From sociological and anthropological perspectives, from both sides the author discusses various studies that have been carried out by Greetz ${ }^{13}$ about scholars as cultural brokers, Horikhosi ${ }^{14}$ about relations and the role of scholars in social change in Sunda, Dhofier ${ }^{15}$ about Kiai and educational institutions and their role in caring for ideology, Mansurnoor ${ }^{16}$ concerning very complex relations between clerics and center of power, and also Turmudzi ${ }^{17}$

11 Syafiq Hasyim, "Fatwas and Democracy: Majelis Ulama Indonesia (MUI, Indonesian Ulema Council) and Rising Conservatism in Indonesian Islam," TRaNS: Trans-Regional and National Studies of Southeast Asia, No. 2019 (2019), 1-15, https://doi.org/10.1017/trn.2019.13.

12 Zulkifli, "The Ulama in Indonesia: Between Religious Authority and Symbolic Power," Miqot, Vol. XXXVII, No. 1 (2013), 180-197.

13 Clifford Geertz, "The Javanese Kijaji: The Changing Role of a Cultural Broker," Comparative Studies in Society and History, Vol. 2, No. 2 (1960), https://doi.org/ 10.1017/S0010417500000670.

${ }^{14}$ Hiroko Horikoshi, "A Traditional Leader in A Time of Change: The 'Kijaji' and 'Ulama' in West Java" (University of Illinois at Urbana- Champaign, 1976).

15 Zamakhsyari Dhofier, "The Pesantren Tradition: The Role of the Kyai in the Maintenance of Traditional Islam in Java" (Arizona State University, 1999).

16 Iik Arifin Mansurnoor, "Islam in an Indonesian World: Ulama of Madura" (Gadjah Mada University, 1990).

17 Endang Turmudzi, Struggling for the Umma: Changing Leadership Roles of Kiai in Jombang, East Java (Australia: ANU Press, 1996). 
concerning changes in the pattern of the leadership of Kiai in Java. Meanwhile, from the historical side study, the author of this article explores two research results. The first was $\mathrm{Azra}^{18}$ about geneology Nusantara scholars with Haramain scholars and also Burhanuddin, ${ }^{19}$ who examined the authority of clerics in the colonial period. The study of ulama and Kiai was elaborated with various studies that discussed power and authority, as carried out by Bourdieu and Weber.

In conclusion, clerics have a very important role in the context of social, political, and economic change. Clerics have a very strategic position at least in the three mentioned fields. However, this study also found that the religious authority of the clerics had been fragmented for a long time. Changes in lifestyle and lifestyle are also very influential in the loss of clerics authority. ${ }^{20}$ In the meantime, there is competition in religious authorities, which is mutually attractive between the traditionalists, reformists, radicalists, and also newcomers. From this research, it can also be proven that religious authorities can run effectively if they walk on the "rails" of power. ${ }^{21}$

If examined more deeply, this article's limitations are due to the lack of reference in the study of scholars that become the basis of literary studies. Only a few studies have been used as references to explore how the authority of the clerics runs in Indonesia. Three sides of the view, namely historical, sociological, and anthropological, also seem to make the scope of this research limited because the Kiai's authority in fact cannot only be seen and approached from the threepoint of view. Moreover, the results of the research from the historical side only come from the two results of research which later were widely denied by historical scientists.

Agrama in Ethic, Tradition, Authority: Towards an Anthropology of The Fatwa tried to review fatwas from a side that is rarely targeted by

\footnotetext{
18 Azyumardi Azra, "The Origins of Islamic Reformism in Southeast Asia: Networks of Malay-Indonesian and Middle Eastern 'Ulama in the Seventeenth and Eighteenth Centuries" (University of Hawaii Press, 2004).

19 Jajat Burhanuddin, "Islamic Knowledge, Authority and Political Power: The Ulama in Colonial Indonesia" (Leiden University, 2007).

20 Mun'im Sirry, "Fatwas and Their Controversy: The Case of the Council of Indonesian Ulama (MUI)," Journal of Southeast Asian Studies, Vol. 44, No. February (2013), 100-117, https://doi.org/10.1017/S0022463412000641.

21 Moch Nur Ichwan, "Towards a Puritanical Moderate Islam: The Majelis Ulama Indonesia and The Politics of Religious Orthodoxy," in Contemporary Developments in Indonesian Islam Explaining the "Conservative Turn" (Singapore: ISEAS, 2013).
} 
researchers, which is viewed from an anthropological perspective. The author of the article tries to view the fatwa not only as a legal product that is doctrinal, but more than that trying to put it and discuss it from an anthropological point of view, including questioning about the nature of temporality and also some other aspects of the fatwa question viewed from an anthropological point of view. ${ }^{22}$ In addition to the main purpose of this article that wants to express fatwas from different perspectives, namely the anthropological point of view, the author of the article from the beginning said that the main reason for choosing fatwas as objects of research observation is based on the characteristics attached to the fatwa which is found observantly. This characteristic is the strength of the authority attached to the fatwa. ${ }^{23}$

From the authors' research results, fatwas have significant strength even though the fatwa does not have the official binding power. The author said, fatwa exercise significant authority even though they are not officially binding, while the court judgment is looked on with great suspicion despite their legally binding status. ${ }^{24}$ This article also concludes that in terms of anthropology, such as the nature of temporality, fatwas are important to be discussed and considered further. The author of the article succeeded in proving that the fatwa-as a legal product that does not have a legal bond to the person who is interested in the fatwa-has limitations regarding temporality. If this is not taken seriously, the fatwa authority will increasingly weaken. The most dominant nature of the fatwa is the elaboration of opinions or past views and then internalizing them with the present, or even future views are closely related to authority. Furthermore, the author of the article notes that the pattern of relations produced by the fatwa, namely between mufti and mustafti, which will later give birth to authority, is a reciprocal patterned relationship. A fatwa is a legal product for certain people, certain cases, at certain times. In this position, the fatwa will of course be positioned by mustafti as not only a suggestion but more as an 'obligation' and also an 'answer' to the problem that is proposed. ${ }^{25}$

\footnotetext{
${ }^{22}$ Hussein a L I Agrama, "Ethics, Tradition, Authority," American Ethnologist, Vol 37, No. 1 (2010), 14.

23 Suaedy, "Pengarusutamaan Fatwa-fatwa Moderat".

${ }^{24}$ Agrama, "Ethics, Tradition, Authority." 4.

25 Suaedy, "Pengarusutamaan Fatwa-fatwa Moderat".
} 
It is unfortunate that the obscurity and negligence of the writer tend to position fatwas as products issued by individuals, not institutions. The case that the writer tried to examine was indeed departing from the case of giving a fatwa in Cairo, Egypt which is actually a style, characteristic, and the rules only place one mufti as the party giving the fatwa. This study becomes less comprehensive because outside of the fatwa model issued by the person, there is also a fatwa issued by an institution as happened in Southeast Asian countries such as Indonesia and Malaysia. It is very important to know more about authority, whether it is born of an individual or built institutionally. Beyond that, the way the writer tries to put the fatwa as a "sociological-anthropological" product is very interesting and becomes its own power. If the fatwa has so far been viewed as a "sacred" legal product, then in my view, the author of this article tries to ground and occupy the fatwa as it is, which is a legal product born of processes, dynamics, and by ordinary people.

In the article titled Bebind The Scenes Fatwas of Majelis Ulama Indonesia (1975-1998), Hosen explores how the production process, methodology, and methods used in determining the fatwa in the Indonesian Ulema Council (MUI). Furthermore, this article also discusses the sources of determining fatwas, the relation between fatwas issued by the MUI on central and regional, as well as the topics of the problems discussed. ${ }^{26}$

This article uses the phenomenological paradigm. Interviews with a number of top officials of the MUI are the data used in this study. The method used is historically materialist. The data analysis method used is interpretive hermeneutic. The conclusion of this article is that the MUI, during its work between 1975-1998, functioned more as a 'semi-government' institution. The MUI is likened to a bridge that connects Islamic organizations. At a certain level, the article writer stated that the MUI often became the 'mouthpiece' of the government in socializing attitudes. The government needs religious legitimacy in justifying its decision, in this position the MUI often stands.

Furthermore, the majority of the MUI fatwas-based on what the article writers found-refer to figh books with little or no modification or further ijtihäd in them. This condition, in the opinion

${ }^{26}$ Nadirsyah Hosen, "Behind the Scenes: Fatwas of Majelis Ulama Indonesia," Journal of Islamic Studies, Vol. 2, No. 15 (2004), 147-179. 
of the article writer, proves that the MUI does not have its own methodology in determining its fatwas. The author said, "it can be confidently asserted that the MUI has not evolved or elaborated its own methodology for the derivation of legal judgment consonant with the spirit and letter of the primary sources, or with legal tradition Islam, and at the same time constructively engaged with the fast-changing realities of the modern world". ${ }^{27}$

What's interesting about this article is the success of the author to investigate and reveal how the initial process of forming the MUI was. This point is not so much known and has also been successfully revealed by writers and researchers before. Especially related to the debate between Ibrahim Hosen and Buya Hamka. If Hosen believes that what Indonesia needs is an institution that has the authority to issue fatwas, then on the contrary, according to Hamka, what Indonesia needs is a charismatic mufti. This means that if Hosen emphasized the importance of institutions, Hamka argued that it was enough for individuals. This debate is recorded as very interesting, as written in this article.

Furthermore, this article also reveals how there are internal problems with the MUI fatwa commission, which are less solid, especially when meetings are in the fatwa termination process. The author of the article revealed that many fatwa commission members were not present and reluctant to attend the fatwa commission plenary meeting to discuss the problems that would be addressed. One of the fundamental problems revealed is the lack of honorarium obtained so that it cannot cover the need for taxi fees.

\section{Fatwa, Religious Opinion, and Oral Society}

Ong in Orality and Literacy: The Technologizing of the $W_{\text {ord }}{ }^{28}$ says, even though the boundary between orality and literacy is very short, it is difficult to identify which pure culture departs from orality and which culture starting from the literacy tradition, actually these two cultural typologies have clear conceptual definitions. If the tradition of orality relies on hearing, the literacy tradition rests on vision.

Based on Ong's classification, it seems like an old discussion about what is actually spoken or written-it is always actual, especially to discuss the thesis's connection with the context of the fatwa

\footnotetext{
27 Ibid., 178.

28 Walter J. Ong, Orality and Litracy: The Technologizing of The Word (London and Newyork: Rouledge, 1982).
} 
tradition in Indonesia. Broadly speaking, among linguists, there is a group of experts that insists on the nature of true language spoken or spoken. While on the other hand, there are also many experts who state that language moves and changes evolutionarily from verbal to writing. These two opinions compete in conceptual language contestation. In this area, the debate about the poetry of Sukmawati is located. If examined in-depth, the two views above actually speak from different sides. The first view goes from the chronological side, while the second is based on the historical-philosophical side.

Orality - as said by Ong - has very prominent characteristics. These characteristics are of course opposite and against at the same time with written traditions or literacy traditions, lack of vocabulary. In the tradition of orality, the main foundation for hoarding the coffers of vocabulary is only memory. So, as long as the memory is maintained, so far the vocabulary is also remembered. Conversely, if the memory fades, the vocabulary is lost. With limited vocabulary, a culture that relies on the tradition of orality tends to be poor in concept. This is the main feature of oral culture.

Because of the limitations of the concept's vocabulary and poverty, people who live in oral culture tend to accumulate and at the same time accumulate many slogans. This is the latest product of the nation in the culture of orality. In this context, it seems that it will be very difficult to argue that from the past until now, we live in conditions of excess slogans and lack of concepts. Although it contains a lot of debate, linguists have standardized where the nation or civilization is still based on oral tradition and which one has started to follow the written tradition. Nations such as the Sumerians, Egyptians, and Chinese-after each finding letters — had a very strong literary basis. They record memories through writing so that their history can be transmitted continuously for a thousand years. On the contrary, nations that do not have a strong written tradition easily experience historical "amnesia": their memories are so short because past events are not well documented.

Borrowing Ong's deduction, Indonesia's condition is in the second position (nations that do not have a strong written tradition). The written tradition of the Indonesian people is not stronger than oral tradition. The main weapon of oral culture is the ear, not the eye. In fact, the Indonesian people's ears are still become the main tool and the most effective weapon to absorb various information. The 
situation in which lazy people read, who like to hear, the reactivereactionary, the myopic symbol, are in one thought with the politisi salon' which increasingly make social conditions so chaotic.

In this context, if we associate with the fatwa tradition, where it is always written in writing, - not verbal- then what happens is the tendency and circumstances in which the fatwa is misinterpreted. In fact, it often happens. The number of people who actually read fatwas, in this context, for example, we take the most phenomenal case 212, very few. Historically, Hosen noted that during this compilation or collection of fatwas that were determined was the result of the highest deliberations in three large Institutions (NU, Muhammadiyah, and MUI) printed and distributed in a very conventional way. Each institution distributes through its respective management networks to the regional level. This condition, which is very limited in distribution, makes the level of readability of the fatwas very minimal. Not to mention if this is associated with the public's interest in reading, which is still classified as very low. ${ }^{29}$

In the context of fatwa that is considered the most phenomenal and attracting attention, namely the fatwa on Ahok, despite that there is such a strong political content, but it is important to underline that the movement relies on the fatwa or religious attitude of MUI on September 11, 2016. Greg Fealy ${ }^{30}$ in his writings titled Bigger than Ahok: explaining the 2 December mass rally said that almost all the mass movements 212 based on the fatwa and religious attitudes of the MUI and initiated by the GNPF MUI (National Movement Guards Fatwa of the Indonesian Ulema Council) did not understand the problem well, they don't even read the MUI's fatwa and religious opinions. ${ }^{31}$ This condition becomes worse when the flow of information is wide open, but not accompanied by adequate literacy skills. It is very clear that this condition is influenced by oral traditions that are still very strong in Indonesian society. An issue became viral spreads from one ear to another without going through a verification process and a

\footnotetext{
${ }^{29}$ Hosen, "Behind the Scenes", 172-173.

${ }^{30}$ Greg Fealy, "Http://Indonesiaatmelbourne.Unimelb.Edu.Au/Bigger-than-AhokExplaining-Jakartas-2-December-Mass- Rally/," 2018.

31 Marcus Mietzner and Burhanuddin Muhtadi, "Explaining the 2016 Islamist Mobilisation in Indonesia: Religious Intolerance, Militant Groups and the Politics of Accommodation," Asian Studies Review, Vol. 42, No. 3 (2018), 479-97, https:// doi.org/10.1080/10357823.2018.1473335.
} 
clear check. ${ }^{32}$ In order to sharpen the analysis, the following is the full text of the MUI's religious opinions or attitudes regarding the Ahok case. $^{33}$

Picture 1.

\section{MUI's Religious Opinion}

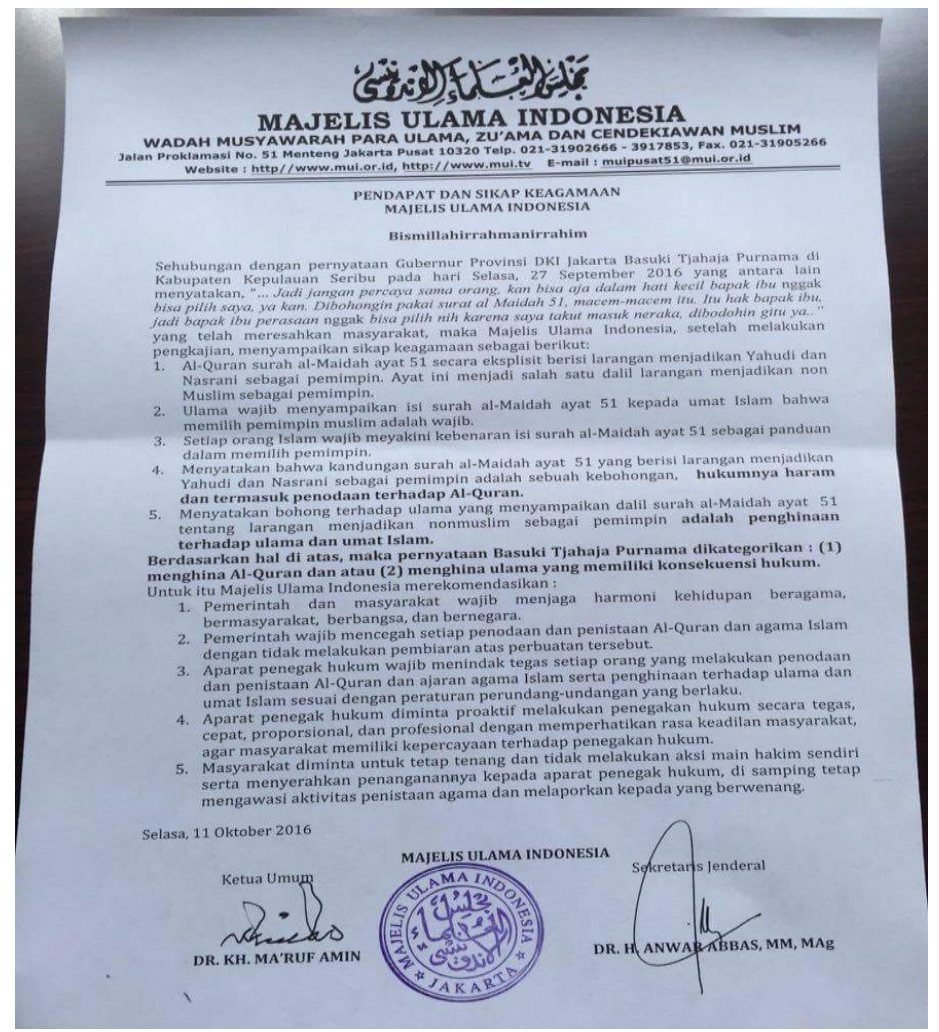

In that dictum, the important point lies in the sentence "Based on the above, the statement of Basuki Tjahaja Purnama is categorized: (1) insulting the Koran and or (2) insulting clerics who have legal consequences". At this stage, it was clear that the MUI considered that the remarks made by Ahok entered the category of insulting the Qur'an. But in fact, the issue echoed by the elite of the National Movement Guard Fatwa MUI (GNPF-MUI) has become wider: defamation of religion. Does

32 Edward Aspinall, "Democratization: Travails and Achievements," in Robert W Hefner (ed.), Routledge Handbook of Contemporary Indonesia (New York: Routledge, 2018).

33 "Menjaga NKRI Bukan Soal Pilkada DKI" dalam http://www.belaquran.com /2016/12/ 
the GNPF not read the religious attitude of the MUI? Of course, the answer cannot be ascertained, but at least based on the indications that exist, if we relate to the traditions of the nation that has oral culture, it is possible that the fatwa is not read. ${ }^{34}$

Even in its official release that was distributed on December 2, 2012, GNPF MUI wrote like this "National Movement Guards Fatwa of the Indonesian Ulema Council (GNPF-MUI) emerged from Muslim disappointment at the blasphemy committed by DKI Governor Basuki Tjahaja Purnama in his speech in front of the Thousand Islands residents on September 27, 2016. The blasphemy made MUI issue a fatwa stating the Governor had blamed the Qur'an on the Al Maidah verse 51. GNPF-MUI was initiated by ulama and habäib, who appointed Habib Rizieq Shihab as the Board of Trustees and KH Bachtiar Nasir as Chairman."

The debate became increasingly interesting because the initial issue about Ahok, which defiled the Koran as well as the dictum of MUI's fatwa, widened into a movement defending the Koran, even defending Islam. A series of actions is called the Aksi Bela Islam. Even in June 2018, a film was released from the action. The film made by director Jastis Arimba was given the headline "The Power of Love"35 One of the most promoted dialogues in the trailer is "Islam is peace and love, rahmah li al-álamin. The radical is your brain." This film wants to give a message to the audience that action 212 is an action based on love, not by other things. ${ }^{36}$

However, instead of (the film) successful, but a citizen repeatedly addresses various comments and negative critiques to the filmmaker. In a survey I did on the film happenings among the students, all of them admitted to being aware. The students split into two major groups when discussing the film's title. Students are divided into two major groups when discussing the film's title. Because the phrase The Power of Love is polemical and

\footnotetext{
34 Jeremy Menchik, "The Politics of The Fatwa" (Boston, 2019). See also Muzayyin Ahyar and Alfitri, "Aksi Bela Islam: Islamic Clicktivism and the New Authority of Religious Propaganda in the Millennial Age in Indonesia", Indonesian Journal of Islam and Muslim Societies, Vol. 9, No. 1 (2019).

35 Hayya The Movie, "Https://Www.Youtube.Com/Watch?V=-Kw3lfjShuY," 2018.

36 Wahyudi Akmaliah, "When Islamism and Pop Culture Meet: A Political Framing of the Movie 212: The Power of Love," Studia Islamika, Vol. 27, No. 1 (2020), 2728. https://doi.org/DOI: 10.36712/sdi.v27i1.920.
} 
controversial. Is it true that those gathered at Monas based love for the Quran? Or just the opposite is based on hatred for Ahok? This question is very difficult to find the answer. However, of course the obvious question at the end of a discussion that appears should be a reflection along with that "if it could be the love of something that is built on hatred towards something else?"

In the meantime, it is very interesting to connect the high oral tradition society with the idea of secularization on the other hand. Abdullah Ahmad An-Naim ${ }^{37}$ has a very popular thesis that the more the state is run by a secular government, the more religious the population is in the country. This thesis is imprecise that the level of religiosity of the population of a country has nothing to do with government regulations. The more the state intervenes in the population's religious affairs, the more the population will stay away from religion.

Long before An-Naim published his thesis, various experts had seriously formulated the concept of secularism. ${ }^{38}$ Broadly speaking, the general idea of a number of secularist theories promoted by past scientists and philosophers states that the transition of a society from an agrarian-based society to an industrialist society tends to make religion unattractive, obsolete, and not counted again, especially in public space. Why is that? Because the character of industrialization requires them to master a number of technologies and bureaucratic devices that are of course modern in character.

This condition is of course contrary to the nature of an agrarian society which still relies heavily on a role model that has authority. Agrarian society cannot escape from what in their minds is called the 'handler', namely an authoritative figure who has the ability and is considered an expert to explain and uncover all kinds of natural phenomena by using religious arguments. ${ }^{39}$

On the other hand, modern society does not need such a handler (mystic shaman) at all. What they need is a scientist who understands and master science on the one hand and is proficient in technology on the other. Two well-known social scientists Pippa Norris and Ronald Inglehart wrote a book that had sparked

37 For more explanation see Abdullahi Ahmed An-Naim, Islam and Secular State: Negotiating the Future of Shari'a (Massachusetts: Harvard University Press, 2008).

38 Abdullahi Ahmed An-Na'im, Islam and the Negotiating the Future of Shari'a (Cambridge: Harvard University Press, 2008).

39 Talal Asad, Formations of the Secular (California: Stanford University Press, 2003). 
boisterous debate titled Sacred and Secular: Religion and Politics Worldwide. ${ }^{40}$ In the book, both of them say that almost the entire community, moving in a direction that is more or less 'uniform': namely towards a modern and secular society.

Of course, this book is actually presented from the spirit of the basic desire to 'test' a number of theories about the early stages of secularization, which have long been established and formulated by a number of philosophers and social scientists, such as Durkheim, Marx, and also Weber. In the view of Norris and Inglehart, the idea of ancient secularization would be a little confused if it was contradicted by the conditions of Western society, which in the years around the '60-'70s were experiencing what was termed a 'wave of desecularization' represented by movements practicing religion in a more inwardly loved by the community. This condition is of course the antithesis of religious practices in a longer form that comes from the church.

Norris and Inglehart in this study proposed a new approach. Both call the approach the term existential security approach. That is a cross-disciplinary approach aimed at examining certain inner states of society based on empirical measurements. The conclusion obtained is that religion's values will tend to be stronger in societies whose demographic structures are classified as disadvantaged, such as having complicated problems of poverty or social problems in the community. This means that the community's life conditions are 'unclear', so that the level of religiosity will be high. The poorer a person is, the greater the need to draw closer to God. ${ }^{41}$

For people who are already complete in the sense of being able to meet the needs of security and comfort, according to this thesis, they no longer feel the need for religion. On the contrary, for poor communities, religion still has a very important and significant role in guaranteeing the quality and survival of a person (his adherent). People who have complicated problems with poverty will feel comfortable, safe, and peaceful with religion because there they think they still get protection from God.

It seems that we have to stop for a moment in reading the Norris and Inglehart thesis above, especially if we connect with the

\footnotetext{
40 Pippa Norris and Ronald Inglehart, Sacred and Secular: Religion and Politics Worldwide, $2^{\text {nd }}$ ed. (Cambridge: Cambridge University Prees, 2011).

41 Ibid.
} 
current conditions in Indonesia. Because we will soon get the facts that are contrary to the secularization thesis that was built by two famous scientists. In Indonesia, we will find symptoms where the level of religiosity has absolutely nothing to do with existential security or guarantee the certainty of life. We witnessed such an abundant religious enthusiasm, the dhikr majlis which was never lonely, and a variety of other religious expressions which were very noisy. Interestingly, as noted by Heryanto ${ }^{42}$ in Identity and Pleasure of most of those who became worshipers of the zikr assembly came from the urban middle class. Even in the present context, the practice of recitation is more of a celebrity question and answer. The ustaz. read one by one the questions of the pilgrims who had been written on the paper. Various questions were also asked, the majority of the problems were worship, although occasionally about aqidab and even politics. Again, this model can also be called the practice of giving fatwas in very traditional definitions.

Referring to the research of the Alvara Research Center in October $2017^{43}$ involving 1,800 respondents from students at 25 universities throughout Indonesia, 23.5\% agreed to the movement of the Islamic State of Iraq and Syria. In addition, 23.4\% agreed on the readiness for jihad to establish a kbiläfah, $17.8 \%$ said that the ideal form of government was khiläfah, and $16.8 \%$ thought that the ideology suitable for Indonesia was Islam. Furthermore, data from BNPT which stated that radicalism fertile land came from Public Universities (PTU), especially the science department. Then how do we read the data and at the same time explain this fact?

There are two alternative answers. First, there could be a valve that is clogged between trends in religious passion, including hobbies in asking for fatwas, with patterns of daily life. Religion is only inside mosques and other places of worship. Outside the places of worship, it is difficult for us to find the spirit and spirit of religion manifest. This condition has been stated long ago by Gus Dur. ${ }^{44}$ In the column titled Da'wah Must Be Researched?, Abdurrahman invited to explore further whether there was a connection between the massive movement back to mosques and houses of worship with religious

42 Ariel Heryanto, Identitas dan Kenikmatan: Politik Layar Indonesia Jakarta: Kepustakaan Populer Gramedia, 2011).

43 Alvara Research Center, "Survey Pola Keberagaman Umat Islam Indonesia" (Jakarta, 2017).

${ }_{44}$ Abdurrahman Wahid, Melawan Melalui Lelucon (Jakarta: TEMPO, 2007). 
awareness. Gus Dur said "Correlation still must be examined between the number of people to the mosque and the religious orientation that has a deeper depth of faith and more meaningful involvement. The most obvious evidence of separating religion from life is not at all related to our social morality and religion."

So, there is a closed valve that directly causes religious patterns to become symptoms of mere formalism and plasticism. We easily get the paradox of those who are passionate about carrying out ritual worship but at the same time build an individualistic lifestyle, even though religion teaches to build a life based on a sense of solidarity and solidarity.

Second, borrowing the thesis of Norris and Inglehart, in the context of Indonesia, life security guarantees (existential security) are indeed difficult to find-not to say there is nothing at all. The fact that radical and puritan groups are born from students with a background in science education is a reflection that those who have a clear picture of the future actually draw closer to religion. On the contrary, we find the phenomenon that students with a background in social education whose future orientation and work area are still grey and abstract (such as the humanities and religion) actually have a high level of immunity towards puritanical and exclusive religious teachings. So that we have difficulty denying the fact that this is truly 'adorable'.

Thus, in a context like this, it is legitimate for us to say that the fatwa in the sense of opinion issued by a religious bureaucratic institution actually gets very little attention. In the context of the MUI, the form and structure of the fatwa, which is becoming more formal by including a kind of consideration, seem to be one of the lighters that trigger increasingly unreadable dictum of the fatwa. If in the past, the structure of the fatwa was very simple in the form of question and answer, the structure of the fatwa was more complicated as the legal decision was taken (by using legal terms: weighing, remembering, deciding).

The structure of the fatwa, which becomes complicated and full of legal decision dictum, even full of references to arguments, is very likely to be a sign that there have been symptoms of the dissolution of authority or the voice of the ulama. If in the past the fatwa was answered directly by the mufti without quoting much of the naqli arguments (Qur'an, hadìth, ulama's vows), then the latter condition 
became the opposite, there was an invasion of theorems crammed into the dictum of fatwas which certainly indicated distrust of opinions and 'sound'. Then the logical choice made is of course by getting and relying on religious propositions.

\section{Concluding Remarks}

Fatwa has an attractive position in the Indonesian context. A fatwa that is persuasive and does not have binding ties to apply later changes in the pattern. There are groups that try to issue a fatwa as a "sacred opinion" or sacred opinion that must be maintained and even guarded and guaranteed to be truly implemented. The causes are indeed not single. In addition to the wave of populism, there are also political factors (sentiments) that contribute to perpetuating this movement.

Interestingly, as a country with a high tradition of orality, the level of fatwa readability is very low. The structure of the fatwa that is impractical tends to use standardized and rigid legal language makes the fatwa readability lower. However, on the one hand, it is possible that the form of a fatwa that resembles the dictum of a legal decision is intended so that the reader believes 'that the fatwa has the binding power as law. Such models and structures of fatwas (resembling legal decisions) differ from those of ancient models and fatwas. Namely, the fatwa was answered directly by the mufti without quoting many theorems of the naqli (Quran, hadith, ulama's vows). The latter condition is the opposite; there is an invasion of theorems crammed into the dictum of the fatwa which of course indicates a lack of confidence in opinions and 'voices'. Then the logical choice made is of course by getting and relying on religious propositions.

\section{Bibliography}

"Menjaga NKRI Bukan Soal Pilkada DKI" dalam http://www.belaquran.com/2016/12/

Agrama, Hussein a L I. "Ethics, Tradition, Authority," American Ethnologist, Vol. 37, No. 1, 2010.

Ahyar, Muzayyin and Alfitri. "Aksi Bela Islam: Islamic Clicktivism and the New Authority of Religious Propaganda in the Millennial Age in Indonesia", Indonesian Journal of Islam and Muslim Societies, Vol. 9, No. 1, 2019. 
Akmaliah, Wahyudi. "When Islamism and Pop Culture Meet: A Political Framing of the Movie 212: The Power of Love," Studia Islamika, Vol. 27, No. 1, 2020. https://doi.org/DOI: 10.36712/sdi.v27i1.920.

Alnizar, Fariz. "Pretext for Religious Violence in Indonesia: An Anthropolinguistic Analysis of Fatwas on Ahmadiyya", Studia Islamika, Vol. 26, No. 3, 2019.

An-Na'im, Abdullahi Ahmed. Islam and the Negotiating the Future of Shari'a. Cambridge: Harvard University Press, 2008.

----. Islam and Secular State: Negotiating the Future of Sharia. Massachusetts: Harvard University Press, 2008.

Asad, Talal. Formations of the Secular. California: Stanford University Press, 2003.

Aspinall, Edward. "Democratization: Travails and Achievements," in Robert W Hefner (ed.), Routledge Handbook of Contemporary Indonesia. New York: Routledge, 2018.

Assyaukanie, Luthfi. "Fatwa and Violence in Indonesia," Journal of Religion and Society, Vol. 11, 2009.

Azra, Azyumardi. "The Origins of Islamic Reformism in Southeast Asia: Networks of Malay-Indonesian and Middle Eastern "Ulama in the Seventeenth and Eighteenth Centuries". University of Hawaii Press, 2004.

Bayyah, Abdullah bin Mahfuz bin. Sināat al-Fatwā wa Fiqh Aqalliyāt. Beirut: Dār al-Minhāj, 2007.

Bunt, Gary R. Islam in the Digital Age: E-Jihad, Online Fatwas and Cyber Islamic Environments: Critical Studies on Islam. London: Pluto Press, 2003.

Burhanuddin, Jajat. "Islamic Knowledge, Authority and Political Power: The Ulama in Colonial Indonesia”. Leiden University, 2007.

Bush, Robin. "Religious Politics and Minority Rights during the Yudhoyono Presidency," in Edward Aspinall, Marcus Mietzner, and Dirk Tomsa (eds.), The Yudhoyono Presidency: Indonesia's Decade of Stability and Stagnation. Singapore: ISEAS, 2015.

Center, Alvara Research. "Survey Pola Keberagaman Umat Islam Indonesia". Jakarta, 2017.

Dhofier, Zamakhsyari. "The Pesantren Tradition: The Role of the Kyai in the Maintenance of Traditional Islam in Java". Arizona State University, 1999). 
Fealy, Greg. "Http://Indonesiaatmelbourne.Unimelb.Edu.Au/ Bigger-than-Ahok-Explaining-Jakartas-2-December-MassRally/," 2018.

Fenwick, Stewart. "Eat, Pray, Regulate: The Indonesian Ulama Council and the Management of Islamic Affairs," Journal of Law and Religion, Vol. 2, No. 2, 2018. https://doi.org/10.1017 /jlr.2018. 23.

Geertz, Clifford. "The Javanese Kijaji: The Changing Role of a Cultural Broker," Comparative Studies in Society and History, Vol. 2, No. 2, 1960. https://doi.org/ 10.1017/S00104175000 00670.

Hasyim, Syafiq. "Fatwas and Democracy: Majelis Ulama Indonesia (MUI, Indonesian Ulema Council) and Rising Conservatism in Indonesian Islam," TRaNS: Trans-Regional and National Studies of Southeast Asia, 2019. https://doi.org/10.1017/trn.2019.13.

Hayya The Movie, "Https://Www.Youtube.Com/Watch?V=Kw3lfjShuY," 2018.

Heryanto, Ariel. Identitas dan Kenikmatan: Politik Layar Indonesia. Jakarta: Kepustakaan Populer Gramedia, 2011.

Hooker, M. B. Indonesian Islam: Sosial Change through Contemporary

Fatawa. Honolulu: University of Hawai Press, 2003.

Horikoshi, Hiroko. "A Traditional Leader in A Time of Change: The 'Kijaji' and 'Ulama' in West Java". University of Illinois at Urbana- Champaign, 1976.

Hosen, Nadirsyah. "Behind the Scenes: Fatwas of Majelis Ulama Indonesia," Journal of Islamic Studies, Vol. 2, No. 15, 2004.

Ichwan, Moch Nur and Noor, Nina Marinani. "Arah Baru Majelis Ulama Indonesia," in Noorhaidi Hasan (ed.), Ulama dan Negara Bangsa (Yogyakarta: Pusat Pengkajian Islam, Demokrasi, dan Perdamaian (PusPIDeP), 2019.

Ichwan, Moch Nur. "Towards a Puritanical Moderate Islam: The Majelis Ulama Indonesia and The Politics of Religious Orthodoxy," in Contemporary Developments in Indonesian Islam Explaining the "Conservative Turn". Singapore: ISEAS, 2013.

Jamaa, La. "Fatwas of the Indonesian Council of Ulama and Its Contributions to the Development of Contemporary Islamic Law in Indonesia," Indonesia Journal of Islam and Muslim Societies, Vol. 8, No. 1, 2018. https://doi.org/10.18326/ijims.v8i1.29-56. 
Kaptein, Nico J.G. "The Voice of the 'Ulamâ': Fatwas and Religious Authority in Indonesia," Archives de Sciences Sociales Des Religions, No. 125, 2004.

Mansurnoor, Iik Arifin. "Islam in an Indonesian World: Ulama of Madura”. Gadjah Mada University, 1990.

Masud, Muhammad Khalid., Messick, Brinkley., and Powers, David. Islamic Legal Interpretation: Muftis and Their Fatwas, ed. Muhammad Khalid Masud, Brinkley Messick, and David Powers. London: Hardvard University Press, 1996.

Menchik, Jeremy. "The Politics of The Fatwa". Boston, 2019.

Mietzner, Marcus and Muhtadi, Burhanuddin. "Explaining the 2016 Islamist Mobilisation in Indonesia: Religious Intolerance, Militant Groups and the Politics of Accommodation," Asian Studies Review, Vol. 42, No. 3, 2018. https://doi.org/10.1080/ 10357823.2018.1473335.

Munjid, Ahmad. "High Demand for Symbols Drive 'Islamic' Black Market"," Jakarta Post, December 6, 2018, http:// www.thejakartapost.com/academia/2018 /06/12/highdemand- for-symbols-drive-islamic-black-market.html.

Nasir, Mohamad Abdun. "The 'Ulamā' Fatāwā and Challenges to Democracy in Contemporary Indonesia," Islam and ChristianMuslim Relations, Vol. 25, No. 4, 2014. https://doi.org/10.1080/09596410.2014.926598.

Norris, Pippa and Inglehart, Ronald. Sacred and Secular: Religion and Politics Worldwide, $2^{\text {nd }}$ ed. Cambridge: Cambridge University Prees, 2011.

Ong, Walter J. Orality and Litracy: The Technologizing of The Word. London and Newyork: Rouledge, 1982.

Sirry, Mun'im. "Fatwas and Their Controversy: The Case of the Council of Indonesian Ulama (MUI)," Journal of Southeast Asian Studies, Vol. 44, No. February, 2013. https://doi.org/10.1017 /S0022463412000641.

Suaedy, Ahmad. "Pengarusutamaan Fatwa-fatwa Moderat dalam Kebijakan Negara: Suatu Tantangan Baru", in Syafiq Hasyim and Fahmi Syahirul Alim (eds.), Moderatisme Fatwa: Diskursus, Teori, dan Praktik. Jakarta: International Center for Islam and Pluralism (ICIP), 2018.

Turmudzi, Endang. Struggling for the Umma: Changing Leadership Roles of Kiai in Jombang, East Java. Australia: ANU Press, 1996. 
Fariz Alnizar, Achmad Munjid

Wahid, Abdurrahman. Melawan Melalui Lelucon. Jakarta: TEMPO, 2007 Zulkifli. "The Ulama in Indonesia: Between Religious Authority and Symbolic Power,” Miqot, Vol. XXXVII, No. 1, 2013. 